Article

\title{
The Reuse of Waste Heaps from Extraction Sites: An Architectural Methodology
}

\author{
Katia Talento ${ }^{1, *(\mathbb{C}}$, Miguel Amado ${ }^{1(\mathbb{D}}$ and José Carlos Kullberg ${ }^{2}$ (i) \\ 1 CERIS, Civil Engineering Research and Innovation for Sustainability, Instituto Superior Tecnico da \\ Universidade de Lisboa, 1049-001 Lisbon, Portugal; miguelpamado@tecnico.ulisboa.pt \\ 2 Earth Sciences Department and GeoBiotec, Faculty of Sciences and Technology, NOVA University of Lisbon, \\ 2829-516 Caparica, Portugal; jck@fct.unl.pt \\ * Correspondence: katia.talento@tecnico.ulisboa.pt
}

Received: 2 July 2020; Accepted: 10 August 2020; Published: 13 August 2020

\begin{abstract}
Nowadays, the rehabilitation of quarries is a widespread practice. It stems from the most significant environmental concern in the management of non-renewable resources. However, reusing quarry waste in the process of regeneration represents the aspect less prevalent. This procedure results from the non-commercialized material, accumulated in huge piles of waste, that constitute invasive elements of the landscape. Because of the intense industrial activity, the wastes further contribute to the degradation of the sites. The result of the waste abandonment could be reversed if this discarded material is considered as a product in the landscape requalification process. Mixing theoretical concepts with practical examples, this article proposes an application methodology to reuse the waste material in the landscape and architectural domains. This new contribution highlights the importance of considering scrap accumulations as an integral part of the architectural project, filling the existing gap in both architectural and theoretical domains. There is not any similar schematization in the literature and the idea of dealing with the mounds of wastes has been only slightly approached until now. The reached outcomes are demonstrative of the possibility of working with the waste heaps in architecture, creating a solid basis for further investigations not documented yet.
\end{abstract}

Keywords: waste reuse; waste-heaps; mounds of wastes; sustainability; circular economy; resource recovery; architecture

\section{Introduction}

In 1913, the artist Marcel Duchamp presented to the public his first ready-made, "Roue de bicyclette." The term refers to an everyday object that arises to a piece of art thanks to the ability of the artist of removing its original use, by exalting it through an operation of choice, casual individuation, or isolation. After more than one hundred years, that operation still preserves a subversive foundation, and it represented a milestone for the definition of the aesthetic parameters of the 20th century. Picasso already brought the "objects trouvés" (found objects, recovered with minimal interventions, and presented as works of art) into art galleries but, on the contrary of the ready-made, they did not lose their original meaning. In reference to his work "Bull Head," a handlebar, however evocative of Taurus horns, it was still a component of a bicycle frame. Duchamp made a waste instead. His bicycle reversed wheel, inserted above a stool, and deprived of its tire, represented a self-sufficient work. It could be admired from the top of a pedestal as a magnificent piece of art. The wheel, decontextualized from its frame, acquired a new meaning and it became, from an everyday object, an artistic unicum. This change of destination of use introduced an innovative notion of art since it promoted values scarcely verified until that moment. Thanks to the conception of the ready-made, the selection prevailed over the 
invention, and beauty corresponded to the essence of an object, undermining the concept of form. For this reason, in the 20th century, the poetic of transformation followed that of creation in the artistic sector [1].

Referring to the architectural field, this understanding was unsuitable for the coeval architecture where the idea of beauty exclusively corresponded to the "new architecture." In this way, there were no connections with the past and the identity of the place. Nowadays, on the contrary, the pre-existing elements influence the concept of beauty and the recovery of many places that can obtain new meanings. These recovery projects enhance the importance of the metamorphosis as a symbol of human continuity that reveals the existent. As happens in the artistic sector with the ideation of the ready-made, the architectural rehabilitation process could not include the operation of "erasing" the traces of the past, but it should incorporate the action of protecting the best cases of architectures and landscapes, as testimonies of the history of the place [2]. Industrial territories are the most representative examples of areas that need rehabilitation processes to preserve their identity. Several worldwide projects exist to demonstrate this necessity [3-6].

Countless man-changed territories represent the motivation of providing a different use to what has been exploited and abandoned. More often, territory changes consist both in the alteration of the place morphology and the presence of many wastes. Nowadays, the rehabilitation of quarries is a common practice; the aspect less prevalent is to include the wastes in the process of restoration. Because of the industrial activity, the wastes, accumulated in huge piles, further contribute to the degradation of the sites. They appear to be disturbing factors, not communicating with the place where they belong, and isolated elements deprived of any use. For this reason, one wrongly excludes the wastes from the process of requalification, preferring to leave them anonymous in the territory, or exporting part of them outside their original place. If one applies the artistic concept for the rehabilitation of quarries, also the significant amount of wastes could be considered as an "object trouvés" or a "ready-made" and arisen to a "piece of art" with a renovated function.

\section{Based on These Premises, What Happens to the Huge Accumulations of Waste?}

After discussing the theory of waste and circular economy, this paper provides a critical survey about some practical examples of reuse, applied to the dumped material in the landscape and architectural fields. This "mix" contributes to the creation of a new application methodology, in the fourth section of the paper, that identifies and organizes the main examples of waste piles reuse to formulate new and principal criteria for their reconversion, filling an existing gap in both architectural and theoretical domains. To the best of the authors' knowledge, there is not any similar schematization in the literature, and the idea of dealing with the mounds of wastes in the architectural and landscape sectors has been slightly approached until now.

\section{Could Waste Become an Integral Part of Our Architectural Design Philosophy Promoting Reuse} Interventions in the Local?

This interrogation represents the key question addressed by the current investigation that promotes the strategy of transforming the inert matter into a valuable resource envisaging new life cycles. The work, described in this article, examines this option by introducing alternative approaches to how architecture can be contemporary without falling into the trap of linear thinking, based on exclusion and separation. The research describes numerous examples of waste reuse in architecture, which consider the discarded material not as a burden but as a renewable opportunity. Section 2 addresses the concept of waste, circular economy, and describes the practice of reuse in a discarded context. Section 3 analyzes the piles of waste material in the architectural, landscape, and arts fields. In this section, the paper selects significant examples of projects conceived with waste material, by differentiating the off-site applications from those in situ, and by elaborating and proposing a useful matrix with distinct hypotheses of reuse. Section 4 proposes an application architectural methodology to deal with the reuse of waste heaps. Finally, Section 5 draws the main conclusions. 


\section{Materials and Methods}

\subsection{Waste Concept and Circular Economy}

Recognizing waste as a chance for the architectural production process, it appears essential to reconsider its definition, introducing the conceptual knowledge of it. The specific meaning of waste is apparently irrelevant but vitally crucial; the notion of waste is far from being obvious, and it has been described by several definitions (listed in Table 1). The common factor is that waste has been recognized as an unwanted or undesired material, which can include fabricated or natural matter [7]. The waste is also something that the possessor has disposed or discarded. Generally, both terms mean "abandonment," but perhaps "disposal" refers to inserting it into a proper place, while "discard" has the connotation of being futile or rejected, set aside [8]. The European Directive [9] prefers to adopt the expression "discard" to expand its reach, including the broadest possible acts of abandonment of things. According to the current European definition, the rejected material is considered more as a potential pollutant than as a possible raw substance [10].

Table 1. Selected definitions of waste.

\begin{tabular}{|c|c|}
\hline Reference & Definition \\
\hline (European Commission, 2008) & $\begin{array}{l}\text { Waste shall mean any substance or object, which the } \\
\text { holder discards or is required to discard. }\end{array}$ \\
\hline OECD, 1998 [11] & $\begin{array}{l}\text { Wastes are materials other than radioactive materials } \\
\text { intended for disposal. }\end{array}$ \\
\hline $\begin{array}{l}\text { (Oxford English Dictionary Online, } \\
\text { n.d.) [12] }\end{array}$ & $\begin{array}{l}\text { Refuse matter; unserviceable material remaining over } \\
\text { from any process of manufacture; the useless } \\
\text { by-products of any industrial process; material or } \\
\text { manufactured articles so damaged as to be useless } \\
\text { or unsaleable. }\end{array}$ \\
\hline UNEP, 1989 [13] & $\begin{array}{l}\text { Wastes are substances or objects, which are disposed } \\
\text { of, are intended to be disposed of, or are required to } \\
\text { be disposed of by the provisions of national law. }\end{array}$ \\
\hline $\begin{array}{l}\text { World Health Organization Expert } \\
\text { Committee, } 1965 \text { [14] }\end{array}$ & $\begin{array}{l}\text { Something, which the owner no longer wants at a } \\
\text { given time and space and which has no current or } \\
\text { perceived market value. }\end{array}$ \\
\hline Wilson et al., 2015 [15] & $\begin{array}{c}\text { Unwanted or discarded materials, rejected as useless, } \\
\text { unneeded, or surplus to requirements. }\end{array}$ \\
\hline Gourlay, 1992 [16] & What we do not want or what we fail to use. \\
\hline Douglas, 1966 [17] & Matter out of place. \\
\hline Steffen, n.d. [18] & $\begin{array}{l}\text { There is no such thing as garbage, just useful stuff in } \\
\text { the wrong place. }\end{array}$ \\
\hline Freilla, 2008 [19] & $\begin{array}{l}\text { Waste is what you call something when you have no } \\
\text { idea what to do with it. The fact that waste exists } \\
\text { anywhere is more a testament to our lack of } \\
\text { imagination. If you have a purpose for it, it is no } \\
\text { longer waste. }\end{array}$ \\
\hline Zero Waste America, n.d. [20] & $\begin{array}{l}\text { A waste is a resource that is not safely recycled back } \\
\text { into the environment or the marketplace. }\end{array}$ \\
\hline
\end{tabular}

From the earliest times, human actions have necessarily produced waste. The Mayan Indians in North America accumulated many types of wastes, arranged in a monthly cadence. Whenever needed, they burned or covered the solid waste with a layer of earth, which resulted in the continuous growth of the ground levels in their villages. Until a few decades ago, wastes, instead of being considered as virtues and resources, embodied a dead-end scenario in which they could be "buried from view" 
as an amorphous matter without value to be hidden. Modernization represents the most prolific and uncontrolled line of production of scraps and waste material; it is a collateral effect of economic progress [7].

The extractive process, being the main topic of this research, designs something disruptive in the waste context. It presents the image of the discontinuity of humanity due to the uncertainty of the industrial activity that, at any time, can terminate producing goods and gains. The "new" cannot be created without something wasted or destroyed. The extraction of minerals assumes that the birth of the "new" requires the death of the "old." In that case, every new creation could share its destiny with abandoned elements to conceive a production even more modern. The extraction activity proceeds through tipping points and embodies a one-way movement, irreversible and unalterable. The chronicle of this type of industry is a cemetery of exploited, repudiated, and abandoned pits; it is unconceivable without waste. At the height of the Renaissance age, Michelangelo proclaimed the precept that led to modern art. He obtained a great harmony of his sculptures using the marble block and removing all unnecessary material. The vision of a perfect form, hidden inside the block of rough stone, precedes his creative act. According to this concept, the waste is the shell that covers that form. It must be denuded of its shell to reveal the features of beauty and perfection. This method transforms waste into an indispensable ingredient of the creative process and gives it the power of transmuting a lowly matter into a valuable object. As the architect Jeanne Gang said, "the materials destined for landfill have begun to explore an architecture originated in the material itself, rather than in a formal language or design concept" [14].

Wastes are simultaneously divine and sinister, since they are the source of the creation and the most fearsome obstacle of it. Therefore, the scraps are sublime: A mix of attraction and repulsion that arouses admiration and fear [21]. They are also valued as gifts, offered by society to itself [22].

According to this citation, the wastes are a gift to release from its "pejorative stigma." They are part of the wealth of society and investments to returning. Talking about wastes means equipping of a specific sensibility. It expresses the inclination to recognize and accept the qualities of existent materials, to transform them, rethinking and reshaping what surrounds us. The reuse is an indispensable component to comprehend how to reprocess an obsolete matter into something that is put back into cycles of use [23]. In other words, the process of reusing materials introduces unique research methods, which appear different from those that often concentrate on beginning from scratch [24]. It is possible to resume these considerations under the head of Tabula Plena.

On the contrary of Tabula rasa, which indicates an operation of design starting with a "blank page," Tabula Plena refers to working with what is already in situ (existing materials and buildings), ready for reconfiguration [25]. This innovative formulation represents the challenge of the 21st century to improve sensibilities around us, reconfiguring the existent to create new places and environments.

The word "reuse" and, consequently, the regeneration of fabricated elements, is also at the core of the theory of the circular economy. This concept often suggests a way to reduce wastes [26] and to protect the environment, continuously using and reusing resources. The circular economy aims to maximize the circularity of matters in industrial society, by designing products and buildings that can be dismantled, repaired, and reused, bypassing the creation of wastes [27-30]. It implies a variation of the utilization, location, or ownership, and it is a concept defined by the imperative to approach climate change, which entails decreasing carbon emissions from human activities [28]. To better understand the concept, one can cite the project of the Bailey bridges [24], representative cases of military reinvention. Today, these are reusable structures for temporary applications such as tennis halls, sports events, funfairs, and store cars in winter. The notion of the circular economy has taken part in human growth since the beginning as an approach to surmount poverty and scarcity of resources. In this regard, the theorist Donella Meadows suggests that scarcity happens when resource streams are forced or exhausted [29]. In numerous situations, it is connected to the availability, energy power of processing, cost of extraction and processing and transport. In the architectural context, scarcity, as suggested by Till and Schneider [30], is more than a lack of supply, energy, or space. It requires a discussion 
of patterns of creation and consumption. The modern conception of the circular economy, instead, is based on overcoming saturated markets and abundance, not a deficiency. The circular economy is ecological because its activities are regional, low carbon, and they use few resources, preserving water, energy, and materials. In this regard, designing buildings with minimum resource consumption during use is becoming mandatory in several European countries. This method represents new challenges to architects, designers, and engineers and it promotes the "throwaway linear culture" into a circular system likened to the ecosystems located in the natural environment (Figure 1a) [24,31].

In the process of the circular economy, three approaches, useful to reinsert the ignored materials in circulation, assume notable importance: "Recycling," "reusing," and "using less." These are the most common strategies that take part in the waste hierarchy, a tool used in the evaluation of methods that protects the environment adjacent resource and energy consumption from most beneficial to least beneficial actions. The hierarchy establishes favored program priorities based on sustainability, emphasizing the importance of waste minimization [9,32] (Figure 1b). It is useful to define the most common approaches of the waste hierarchy to understand the subtle differences between the strategies to adopt:

Recycle: It is any recovery process, which reprocesses waste into materials or products, for the original or other purposes. It includes composting but not incineration. Although the process reduces the quantity of waste, considering it as a valuable stock, it involves the consumption of a consistent amount of energy and water.

Reuse: It means giving the products a second life before they become waste. There is not a reprocess of the discarded material and, consequently, the significant carbon footprint associated with the recycling operation. The value of the waste resource can stay the same or it can increase. This method requires creative designers that recognize potential in the discarded materials. In this case, one also refers to "superuse," a method that differs from the simply "reuse" for the need to propose future scenarios for the rejected material. In this way, it becomes more beneficial than before considered [33]. The practice of reuse comprises three levels of preparation for secondary use:

- Direct reuse: The elements are used as close as possible to their original status and for their original purpose, needing almost no preparation.

- Renewed use: The operations of cleaning, renovating, repairing, or remanufacturing lightly alter the materials to serve a new function.

- Rethought reuse: Reclaimed materials are combined with others to produce a secondary good with a new utility [34].

- The advantages of reusing components can be found in various sectors:

- Design: The creation of new materialism;

- Environment: Reducing waste disposal, gas emissions, and climate change;

- Economy: The local stock of resources leads to an improvement in local employment;

- Resource conservation: Possibility of creating materials from primary resources;

- Social: The birth of a new approach of respect towards the built surroundings.

Using less: Ability to minimize the amount of material used during their whole life cycle.

In this regard, it becomes essential to mention the opinion of the architect Jeremy Till: "As we move from the industrial age to the digital age, this provides an opportunity for a new way of thinking about materials. Products should not have a life but should be part of an ongoing technical cycle" [30]. 


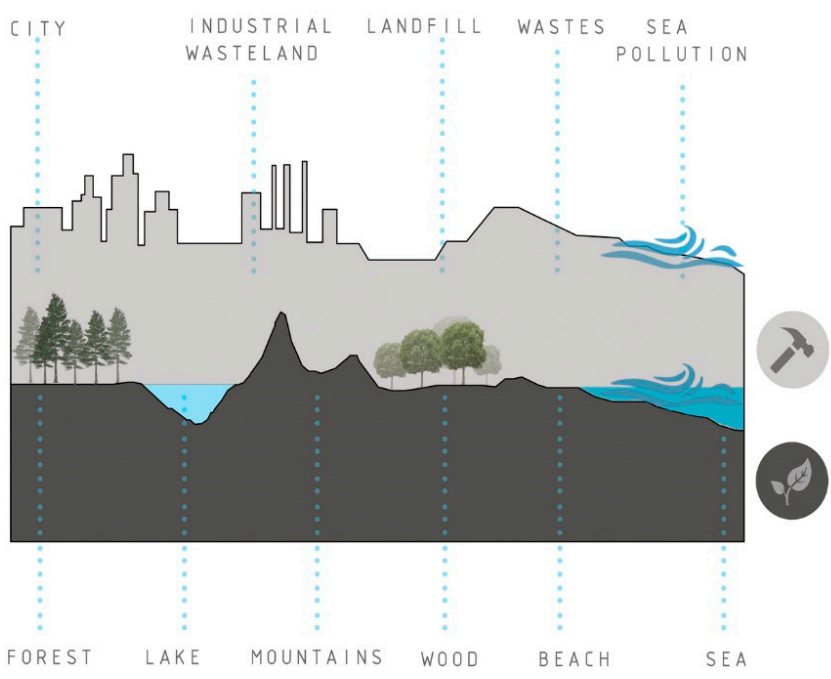

(a)

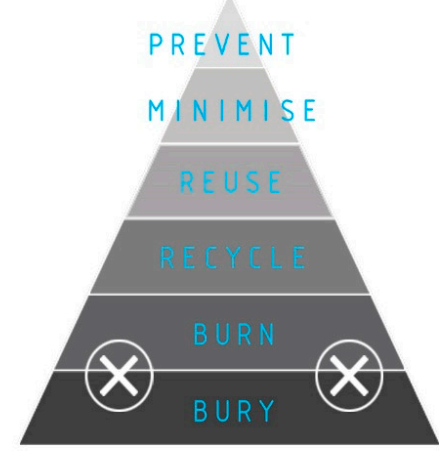

(b)

Figure 1. (a). Mining the Anthropocene + cultivating natural resources. (b) Waste hierarchy. Source: Authors.

Being the main topic of the research and being the operation more advantageous from the economic and energetic point of view, the strategy of reuse represents the core of this paper.

\subsection{Unwanted Material and the Practice of Reuse}

The idea of using the place and the surrounding area as the first spot to look for resources is extraneous to most contemporary designers. However, in the past and still today in specific parts of the planet, discarding materials was not an option, since working with new matter appears expensive [29]. The practice of reuse, although episodic, has always accompanied the history of building. Humanity has always had problems finding resources, since the time of our hunter-gatherer ancestors 10,000 years ago. People have not stopped utilizing and wasting resources and living sustainably does not merely impact human societies. For this reason, we are in the middle of the mass extinction of species, and several resources are limited and hard to access [24]. Kevin Lynch, in his treaty on waste, provided us with some examples of waste reuse since antiquity. He declares that in ancient cities, old monuments were used as quarries for stones, beams, or roofing materials. A Roman Imperial script, in 397 b. C., authorized the oriental Prefect to use the material of the demolished Pagan temples for the maintenance of public bridges, streets, aqueducts, and shafts. An additional case is related to the big fire of London where an enormous amount of old rubble, transported by ship as filling material, created the new Russian city of St. Petersburg [35]. For the construction of Notre Dame du Haut chapel in Ronchamp in the 1950s, even Le Corbusier decided to include masonry walls built from stones recuperated from another ancient chapel [29].

Since the Industrial Revolution, the consumption of natural resources has risen significantly and unsustainably. Nowadays, nearly $90 \%$ of raw materials are destined to become waste, while $80 \%$ of products are dumped within the first six months of their life [36]. This conception is crucial to realize that it is necessary to reuse the discarded material to limit its capacity on the territory [37]. The construction industry, succeeded by the mining and quarrying industries, is still the most abundant source of waste generated annually in Europe, producing $36.4 \%$ of discarded material in the first case, and $25.3 \%$ in the second [38]. Generally, all human consumption, in every economic activity, is annually responsible for almost 2 billion tons of waste, which increases year after year as populations and urbanization grow in all corners of the world [39]. The actual world population (7 billion) is expected to rise by $41 \%$ by 2050 . The problem is that the world does not have enough natural resources, 
and there is a need to alter human demand, instead of discarding things [40]. In a society confronted with climate change, enhanced resource scarcity, and other environmental, economic, and social difficulties, access to new resources and the disposal of scraps are becoming far more expensive and restrained. For this reason, it is essential to "absorb" the enormous piles of wastes, accumulating on the territory, and the rising cost of disposal. From these data, it is feasible to create new and different business opportunities without damaging natural resources and thinking about architecture as a tool to "discover" local and pre-used materials, not always associated with new technologies and the most innovative materials [40].

The modern mind supports the idea based on the change of the world. Modernity is to refuse its actual state and to decide on transforming it to reduce waste. By the turn of the 20th century, waste represented the most significant problem of society and, during the 1980s and 1990s, recycling and reusing programs began to rise in the industrialized world. At this time, the waste products exposed a diverse story: That of wasted resources [7]. Some European countries, such as Belgium, the Netherlands, and Denmark, recycle/reuse between $95 \%$ and $97 \%$ of their waste. Denmark represents the most significant case thanks to the approval of a law in 1988, that imposed to the building companies the reuse of the discarded material from excavations, demolitions, and constructions. This country has been a front-runner in investigating the implications of circular practices, recognizing that the products/buildings in a system need less energy, to produce fewer gas emissions, and diminish the demand for raw materials. This premise is essential to understand that the contemporary world is beginning to consider unwanted material not as a separate entity but as a component connected with the building sector. According to this logic, waste is the consequence of any human action and interaction, bringing natural raw material from one stage of being into another, by applying different forms of skills and energy. As the architect Joachim Mitchell affirms, the discarded matter is understood as an integral part of a resource and the future city makes no distinction between waste and supply [41].

The waste might become so attractive that it makes reason to grow more of it [7]. For thousands of years, cities were designed to produce waste; nowadays, on the contrary, it is the time to design waste for the regeneration of cities. How could waste and urban development combine? The first approach to consider is the reduction, thinking about a radical reuse plan [42]. According to the first step of the research methodology followed in this paper, a meticulous and selective bibliographic research has elaborated the waste reuse theoretical notions (described so far). The references have been searched for keywords, mostly related to the concepts of waste, waste reuse, and stone wastes. The bibliography was then organized following the paper purpose, namely that of generating a fluent reading about the waste concept, from its origins to its contemporary applications. As described in the following sections, this solid background represents the starting point to discuss the waste reuse plan in the practical sector, which can occur using two distinct tactics: Off-site reuse and in situ reuse.

\section{Results}

\subsection{Building with Stone Wastes: Off-Site Reuse Applications in Architectural, Landscape and Art Sector}

Nowadays, different types of wastes exist around the world. Among the most popular, one can find plastic, paper, glass, radioactive, medical, biological, chemical, industrial, solid, hazardous, agricultural, and demolition and construction wastes. They represent distinct rejected materials with specific properties and origins. The common factor that connects all these wastes is the possibility to re-introduce them in a new life cycle, generating at the same time new functions and uses, instead of demolishing them. It is also evident that not all waste materials are suitable for this approach. Chemical, radioactive, and medical waste products need special treatment, and they are not a part of the current work. On the contrary, the research topic pays attention to industrial wastes, especially those from quarries that have lost their meaning.

In the architecture field, among the innovations of the constructive culture regarding the alternative use of wasted stone, it is necessary to mention the "gabions technology," which transfers a technique, originated and well established in the world of water and road works, to the architectural and 
landscape field. This system is primarily recurrent in landscape design and numerous projects of quarry reconversion. The most ancient testimonies relate to the use of mats and vegetal baskets, for the transport and consolidation of piles of stones and ground, dating back to Sumerian, Babylonian, and Egyptian civilizations. Since the modern age, this method spread for the construction of military and waterworks, introducing the use of wire containers. If in the past gabions were produced in situ, nowadays they are prefabricated and appropriate for many architectures and landscape utilizations [43].

One of the first applications concerns the project of the architect Enric Miralles of the Igualada Cemetery (Figure 2a). It represents the regeneration of a former extractive area where the designer introduces the use of gabions technology as self-supporting walls. In this way, one defines both a containment system and facades configurations, "imprisoning" salvaged stones of the quarry, using a wire netting. Other recovered elements, evocative of waste processes, are embedded into paving. Beyond the powerful landscape integration, gabions have notable quality performance related to the operation of reuse and recycle.

In this regard, the architect Alfonso Acocella affirms that gabions are permeable to air and, at the same time, they have high thermal inertia. They are inexpensive, easy to transport, and durable. Moreover, gabions do not require maintenance, they are modular, removable, and they can be reused. Furthermore, they can also contain recycled material as filling, since their first fabrication [43]. Many other projects, from different architects and with diverse purposes, apply the technology of gabions to limit the enormous amount of waste, located on the territory, from extraction activities (Figure $2 b, c$ and Figure 3).

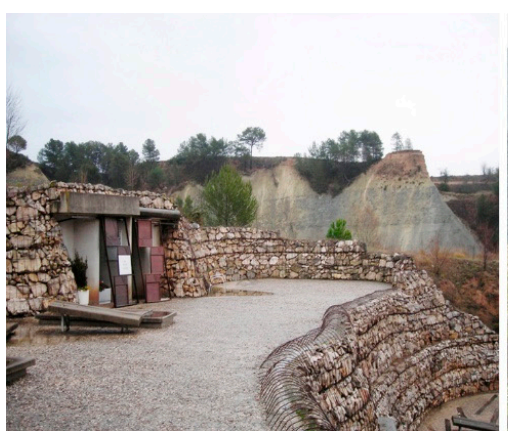

(a)

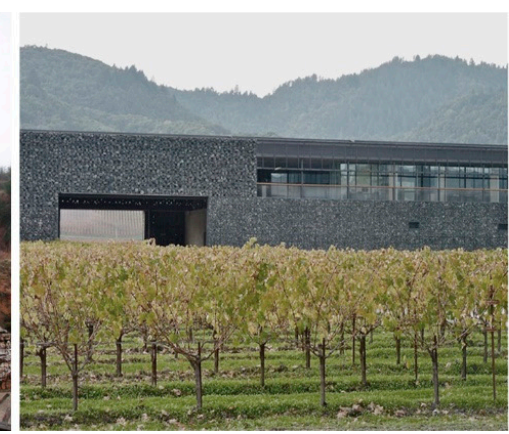

(b)

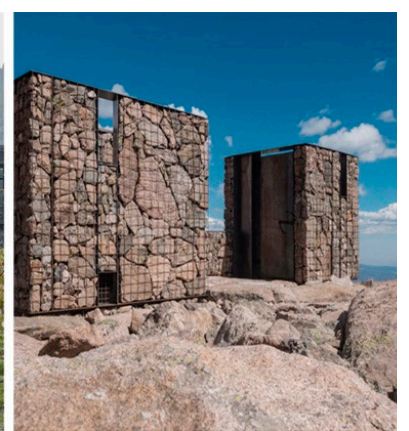

(c)

Figure 2. (a) Igualada Cemetery, Spain. Source: Trekker. (b) Adega Dominus, Napa Valley. (c) Long Peak Toilet, Colorado(C Colorado Building Workshop/Rick Sommerfeld.

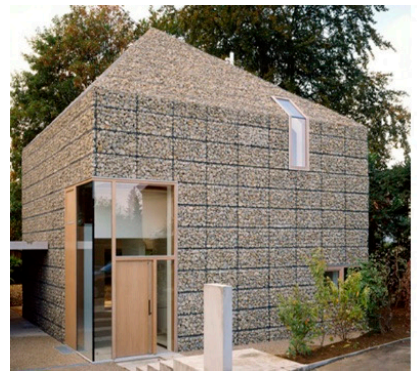

(a)

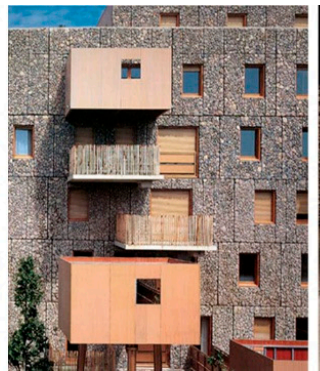

(b)

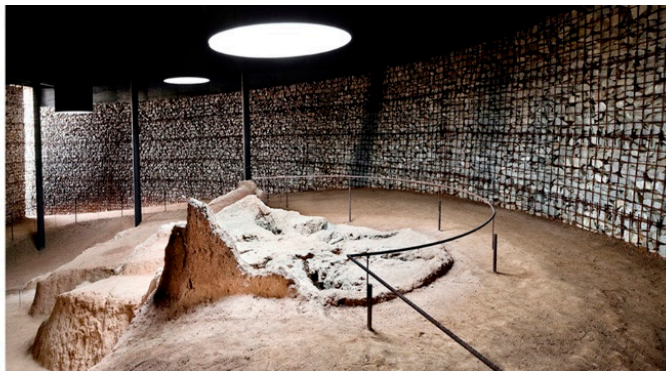

(c)

Figure 3. (a) Private House, Stadtbergen. (b) Social housing in Montpellier. (c) Discovery of three Roman industrial furnaces, Spain (C)Adrià Goula.

This technology denotes the most popular and practiced type of reuse of stone waste from quarries. It mostly represents "off-site" reuse, which means to take the discarded material from the extraction sites and to transport it outside the area where it resides, to create new components for architecture 
building or landscape elements. Beyond the impressive gabions approach, stone residues are reused for the composition of building facades and walls or the covering of internal spaces. In the first case, there are many ways to design building facades with residual rocks, and it can happen using only stone without containers and binders or panels composed by the residual substance.

Mortensrud Church represents an exemplar case regarding the realization of building facades, composed of residual stones without the use of wire netting or mortars (Figure 4a). The church stands on the top of a hill, in a dense pine forest outside Oslo, and was designed by Norway's Jensen and Skodvin Architekten. Instead of removing the sharp rocks and irregularities existing in the place, the architect's concept centered on including these natural elements into the building. The principal structure of the building is a framework of fixed steel profiles, stabilized by horizontal beams. The walls are a mixture of slate stones and glass, with the slate walls withdrawn from the glass facades, allowing for narrow passages on either side of the nave. The stone in this wall is built without mortar, thus letting in light, and has one regular side and one irregular as standard. The stone wall is set horizontally by steel plates that span between the columns, inserted into the wall, every meter [44].

It is feasible to create waste building facades also through the formation of covering panels with stone scraps. A project which deals with this approach is Apartment 1 of the architect Mehdizadeh in Iran. It represents an apartment building, with commercial spaces, produced entirely with waste from local quarries to respect sustainability principles in the architecture field (Figure $4 b$ ). Due to the intense extraction activity, the designer, having available an enormous quantity of scraps, decided to stimulate local players toward energy savings and reduction of global costs of construction. He designed exterior covering panels by overlapping different types of waste, such as marble, travertine, and granite. In this way, the architect created high surfaces with mixed chromatic and tactile nuances [45].

The concept of covering building surfaces with stone waste can also apply for the interior spaces of a construction. Valentino New York flagship store, designed by the architect David Chipperfield, expresses one of the most outstanding projects where the abovementioned suggestion is practiced. By merging old and new, the store idea makes a palazzo-like atmosphere, steering away from a showroom appearance of a typical boutique and developing a more architectural retail format instead. Architectural components are at the heart of the design notion. Architecture is brought into the shop rather than persisting only on the exterior, thereby decreasing the use of superfluous decoration and thin panels to generate an interior scenography with the use of recycled marble waste for the covering of walls (Figure 4c). Architectural characteristics, such as columns, staircases, and walls continually expose their fundamental materiality and complement the pieces on display [46].

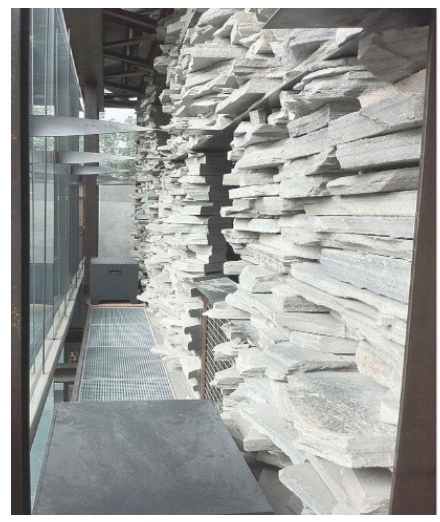

(a)

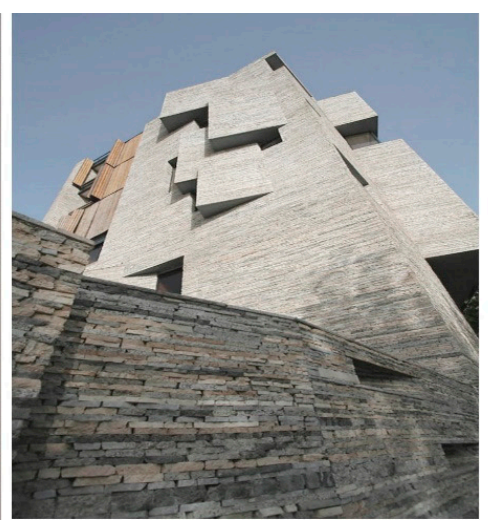

(b)

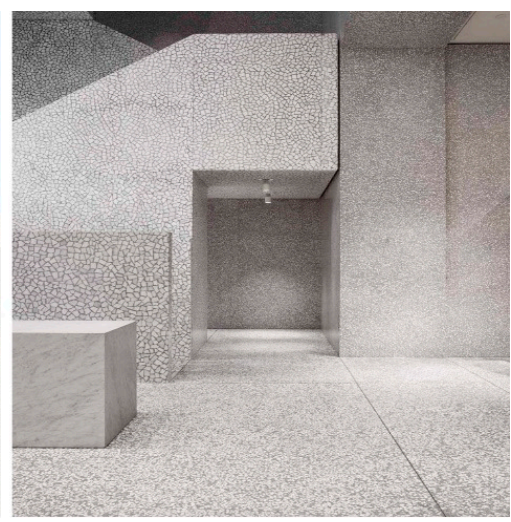

(c)

Figure 4. (a) Mortensrud Church, Norway. Andrewrabbott CSA_3.0. (b) Apartment 1, Iran. Architecture by Collective Terrain Architect: Ramin Mehdizadeh @OOmid Khodapanahi. (c) Valentino New York flagship store @Santi Caleca. 
The technology of reusing stone wastes to limit their impact in the territory is also present in the landscape field for different purposes. Wastes are the best means to enhance the meaning and the memory of a place. Raw stones appear to be the best example of materials to reveal the history of a place, jointly with its mutations and "sorrows." Memorial parks often manage this type of scrap to emphasize their past. A relevant case is the Belzec Memorial Site in Poland. This project was founded in 2004 with the responsibility of documenting and commemorating the Jewish victims of the German death camp in Bełżec. The memorial site, prepared by a group of artists, exposes the cold and brutal strength of the place on the border of life and death. It is a site where all the arts converge, where the scale is gigantic, but at the same time, the artistic language is reserved, free of naive statuary or Motherland symbols. A large rectangle of several hectares represents the cemetery without tombs, and it is entirely covered by a layer of specially prepared material (stone wastes mixed with cinders and sterile soil), which creates a black spot in the green Roztocze Lubelskie countryside (Figure 5a) [47].

Through this strategy, the landscape sector takes advantage of waste also to magnify the industrial memory of a place. It is the case of Piedra Tosca Park, located in the Natural Park of the Garroxta Volcanic Zone. The basaltic flow from the volcano partially generated the area. The strenuous work of humans to cultivate a small portion of land, accumulating all the rocks, stones, and gravel in deep walls, tombs, and barracks, also contributed to the formation of the park. It is a particularly unique site, a sea of wasted rocks (Figure 5b) [48]. Other applications are detectable in the landscape field, such as those related to public parks and outdoor items of furniture. For these purposes, one usually uses gabions technology (as previously mentioned) to create gardening elements such as paths, partition walls, seats, flowerbeds, and fountains.

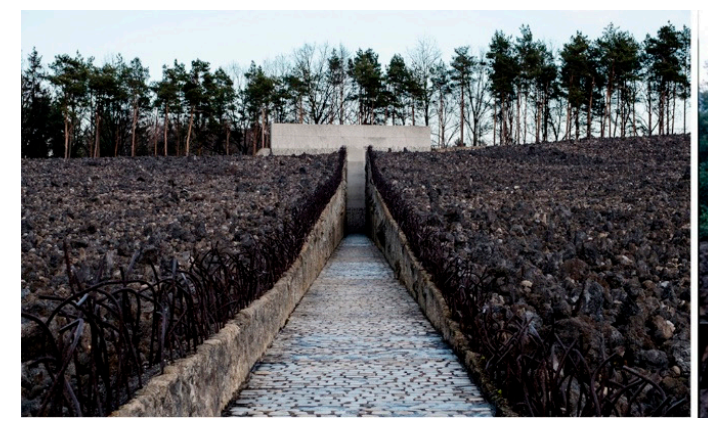

(a)

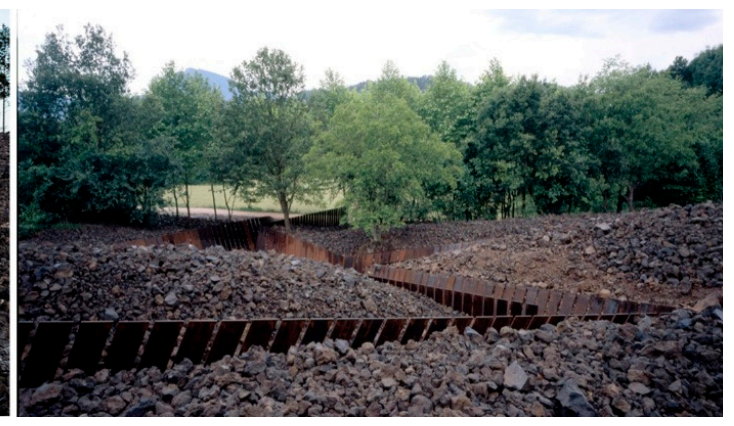

(b)

Figure 5. (a) Belzec Memorial Site, Poland (CGiovanni Carrieri. (b) Piedra Tosca Park, Natural Park of the Garroxta @RCR Arquitectes.

The art sector was the pioneer of the concept of reusing waste, thanks to the work of land artists that have recognized the importance of the shared topic. In 1967, Robert Smithson explored the industrial areas around New Jersey, and he painted them as the equivalent of antiquity monuments. Captured by the swirling pattern of brittle rocks, the artist found in those wasted areas a petrified sea with many stratigraphic horizons and endless directions of steepness. Following his idea of art based on the notion of limit, Smithson imagined containing that "oceanic site" through a sculpture; installed in 1968, a trapezoidal wood box enclosed the uneven fragments of the slate quarry in Bangor, Pennsylvania [49]. He described the installation as a three-dimensional map of the quarry, a piece of an already fragmented landscape. This work, titled Non-site, is one of the numerous Non-sites, which the artist created that year. In each of them, he carried matter from extraction sites, especially mines and quarries, and placed them as sculptures, adjacent maps, and other documentation of the original place, into galleries. Despite the location in gallery spaces, the installations represented means for dialectical thinking, and they projected to the place and back again [50]. 
These pieces referred to the spot that they came from and to their human, historical, and geological mutations and they were not only fixed objects. Material relocations and their diversity connected the sites and non-sites. Sites were physical, peripheral and they supplied means for urban development; non-sites, on the contrary, were abstracts and central concentrations of cultural capital [51]. Sites were the "signified" and non-sites were the "signifier." The conception of the land artist Smithson examines, in the art field, how the production of the landscape in one area is related to its alteration elsewhere, by exalting the place of material production and denying the place of consumption [52].

The most numerous uses of stone waste from quarries concern the industrial sphere, which proposes ideas to recycle the residual matter. Recycling and industrial concepts are out of the scope of the current research, which, on the contrary, is concerned with the reuse of waste material in the architectural and landscape sectors, having more economic advantages. At the same time, the article provides a brief explanation regarding the recycling method to understand how and in which field it is possible to use the scraps from quarries. Their applications are so abundant and spanning from the glass, steel, metal, plastic, chemical, pharmaceutical, environmental, agricultural, textile, and construction industry to public works. Those that can reach to high consumption of the scraps are faced to civil construction industries (for the production of concrete, lime, and cement), to the agricultural field (for calcining acid soils), and to the civil engineering sector (for the production of bituminous composites, useful to aerodromes and road construction) [53-55]. A different aim is to take advantage of the discarded matter throughout the active period of a quarry to reduce the unused stone waste heaps that provoke a strong impact in the landscape. This idea proposes to use and recycle the leftovers for the creation of an innovative material, titled "marcrete" (a merging of marble and concrete), to apply in the architectural area. All these examples consider the wastes as elements to use elsewhere, aiming to exclude from their original location $[52,56]$. Future directions on the topic suggest acting in situ, not exporting the material.

\subsection{Reuse Applications In Situ}

Today, although there is a positive willingness to apply reuse strategies for the waste material (coming from quarries and other extraction sites) to decrease its repercussion in the territory, this is not enough. The amount of waste is so severe that the operations of reutilization cannot involve all of it but only small percentages, compared to the totality of wastes. Industrialization has advanced so far that, on the one hand, human activities have taken over the natural aspects of the environment and, on the other hand, they do not know how to manage the industrial leftovers that cannot be reused.

Based on This Evidence, What Happens to the Remaining Part of Wastes?

Practical answers to this question do not exist. The unique alternative is to accumulate the leftover material in giant heaps, since the hypothesis of demolishing it is unaffordable from an economic point of view. In this way, one treats the mounds of waste as burdens, abandoned components, the function of which is only that of defacing the landscape. They are anonymous elements, not communicating with the landscape, and society refuses them due to their extraneous aspect. Discordant with this attitude, the current research attempts to propose working with the artificial mountains of industrial waste from extraction sites because they are the most intricate and fragile part of the territory. Considering these accumulations as indispensable components of the landscape represents a challenge, and it involves future extensions of the cities, re-imaging the discarded elements of our wastelands. The giant piles need to be re-introduced in a cycle, from a landscape and architectural point of view. The inert matter is not an obstacle to overcome, but an occasion to restart and remodel the territory with the contributions of architects and planners.

Moreover, they also could be innovative elements to generate new economies for society. After providing a background on the waste reuse topic, the current investigation intends to put at the center of the architectural discipline, the contemporary problem related to the presence of enormous mounds of stone remains in our landscapes. The architecture field has the duty of considering 
these elements in the process of rehabilitation of the territories, jointly with the quarries' (and other extraction sites') regenerations. The waste heaps cannot go unnoticed because, following human transformations, they turn into contemporary landmarks of the cities. Skyscrapers, towers, cathedrals, memorials, monuments, bridges, installations, and sculptures are not the only ones. Landmarks are also those produced from industrial activity, composed by waste, which are becoming integral pieces of our environment, being repository and testimonies of technical, human heritage and local identity.

For this reason, the present investigation contributes to this innovative theme, by analyzing a massive area in Portugal constituted of numerous and giant heaps of waste from marble quarries (Figure 6a,b, Table 2). These heaps are nearly two hundred (one at each quarry), and they are part of the Estremoz Anticline in the Alentejo region. Before conceiving an architectural approach and a renovated function to the artificial accumulations of residues, it is essential to realize what exists concerning these "unfamiliar" industrial elements. The bibliographic search is extremely complicated due to the absence of sources and records, and most documented waste piles are mainly originated from the mining activity. Most of them appear to be disregarded and abandoned in the landscape, "silent" and deprived of a role. Despite being massive and impressive, they only continue to represent the background of the urban or rural scene. Mining activities are the primary producer of accumulated wastes, followed by wastes extracted from quarries. As illustrated in the following table, these accumulations, even without a function and recovery interventions, embody the aspect of new contemporary monuments, which deserve protection measures (Figure 6a-i).

Due to the complexity of going beyond the traditional limits in the architectural context, the reuse interventions of a mound of waste material are considerably restricted. Because of the lack of bibliographic sources in the architectural domain, it is more complicated tracing few examples in which the large piles assume new meaning. Until now, the operations of reuse rely on ephemeral or small interventions and mainly include a recreational and touristic use to promote the industrial heritage. The community of Blaenau Ffestiniog located in the heart of Snowdonia National Park in North Wales, represents an exemplar case, which pays attention to the industrial memory of the place, valorizing it as much as possible. The park, besides being recognized for its lofty peaks, it is also known for its magnificent scenery, composed of vast slate mines, caverns, and massive waste heaps [57]. In this locality, an attractive touristic system has been designed, and safari tents, immersed in the industrial landscape, which observe the industrial remains, form it (Figure 61,m). This type of intervention consists of introducing small ephemeral structures in proximity to mines and slate waste piles, not interfering with them. If, on the one hand, it can be interpreted as a timid approach, on the other hand, it respects and valorizes the pre-existence by contemplating it.

A different strategy of reuse is that of physically working on the waste heap through little interventions. Weldon Spring Centre, located in St. Charles County, Missouri, once was one of the most toxic places in the United States. During World War II, the American Government built a munitions plant on the property. Old bunkers used for the storage of TNT (trinitrotoluene) explosives still dot the landscape. Later, EPA (United States Environmental Protection Agency) Superfund used the site to reprocess TNT and uranium and decontaminated the land. Despite that, the giant mound of nuclear waste persists in the territory, and they were equipped with staircases to permit the visitors climbing it and capturing beautiful views of the surrounding area (Figure 6n,o). Nowadays, the conservation area includes forest, woodland, cropland, grassland, sand flats, lakes, ponds, and wetlands. It has developed into a valuable wildlife habitat, and it offers a wide variety of recreational opportunities for tourists, including fishing, hunting, hiking, and biking. Albeit in an embryonal form, this method shows the desire of treating the accumulation of scrap like the other components of the landscape. According to this view, the waste accumulation represents not an isolated factor to monumentalizing but a territorial component able to interact with people.

The union of these two elements, monumentality and human interaction, is interlaced in the Dionyssos quarries in Greece, always used for the extraction of marble. Following the idea of the creators, the marble quarries deserved to be celebrated and they conceived an open-air museum 
to observe the extraction safely. The landscape sculptor Nella Golanda and the architect Aspassia Kouzoupi treated the quarry as an impressive sculpture thanks to the "absorption" of the waste embedded in the pit, according to a fascinated artistic vision. As a result, the waste faces had become a sculptural composition that revealed the lines of the rocks. The museum consists of a series of small structures and paths through the old quarry, built without the use of mortar or concrete. The designers also wanted the site to contain surprise factors such as the climb ends in a hollowed belvedere with a marvelous view of the sea (Figure 6p,q). Applying conventional industrial methods, they have produced a post-industrial landscape of sublime richness [58]. If the previous examples were considered separately, in this case, Dionyssos quarry includes both monumentality and the interaction components, exalting the place as a prominent rock installation, opening it at the tourist excursions.

Slag heap Haniel, in Germany, adopted a more naturalistic approach. It is the highest elevation in the Ruhr region [59], and it appears camouflaged in the surrounding landscape, resembling a natural hill of the territory. This heap is treated as an integral part of the landscape and not as an extraneous object to contemplate. For this effect, the reuse process consists in the creation of a large park, in the southern part of the heap, while the northern one continues to be used by Prosper Haniel Coal Mine. The waste pile blending in the context in the way of which the recreational structure for cultural events, the amphitheater, is placed in the "crater" of the slag heap (Figure 6r). It is hiding on the top of the "mountain," inside an artificial "valley." In this manner, Slag Heap Haniel is suitable for leisure and entrainment functions in respect of the naturalistic feature.

Beyond the recreational and touristic purpose, there was an attempt to reuse part of the waste, accumulated in piles, also for different and more specific functions, such as religious. In Helsinki, an unusual building, Temppeliaukio Church (also known as Stone Church) was built from a combination of solid rock and waste blocks carved out of a granite stone hillside (Figure 6s). The domed construction is not inserted within an industrial context but at the center of the city where there are not quarries, mines, and enormous mounds of wastes in the location. The granite wastes are united with the solid block of stone for the creation of a new structure inside it. Due to the peculiarity of the project, the research also considers this reference. Building inside a combination of rocks and wastes could represent a basis for future investigations to apply to the mounds of wastes from quarries.

This schematization represents the application of the theory about waste reuse and circular economy (previously described in Section 2) in the practical field, through the selection of significant cases of study in which the attempt to reuse the waste heaps (albeit in an embryonal form) is evident. The matrix also embodies the figurative synthesis of the research methodology followed by the authors in the paper, which contains both the theoretical and practical foundations for deriving, in the fourth section, the application methodology for the reuse of waste heaps. Being a theme with lack of fundamental and applied research, and having available a limited quantity of sources, it was difficult to search for cases of study that show the process of reuse and conversion of the waste piles. As a consequence, it was easier to select a set of cases among those found. As for the theoretical section and for the practical part, the best examples of reuse have been identified by keywords, mostly related to the concepts of waste reuse, mine/stone waste, and quarry regeneration. Successively, the designated cases of study have been differentiated in typologies of intervention (off-site and in situ), deepening that in situ, being part of the main purpose of the research. From this selection, the existing approaches of reuse have been investigated to compose a general matrix with distinct hypotheses applicable to the piles of remains. The obtained results are divergent from those already published. While the majority of the literature is focused on the recycling of the waste material in the industrial sector [49-53], the current scientific method shows the possibility of approaching the practical reuse of waste heaps, in the architectural and landscape sectors, through the definition of classes of reuse (Table 2). 
Not Reused

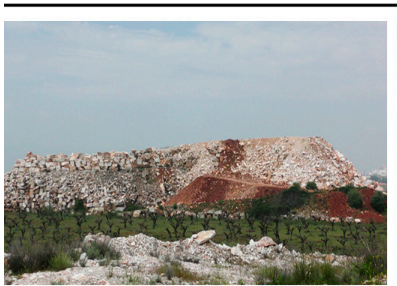

a,b)Marble. Estremoz Anticlinal, Portugal. b) Author: Katia Talento

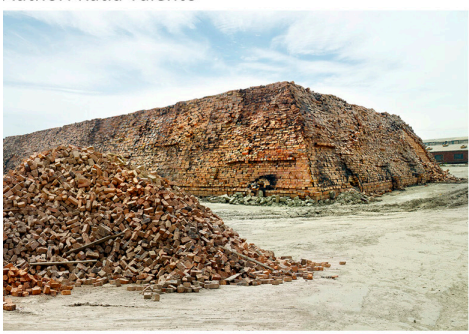

c) Brick Factory, Cape Town

OMarkku Lahdesmaki

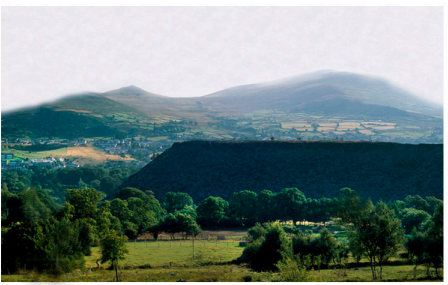

e) Slate. Bethesda, North Wales.

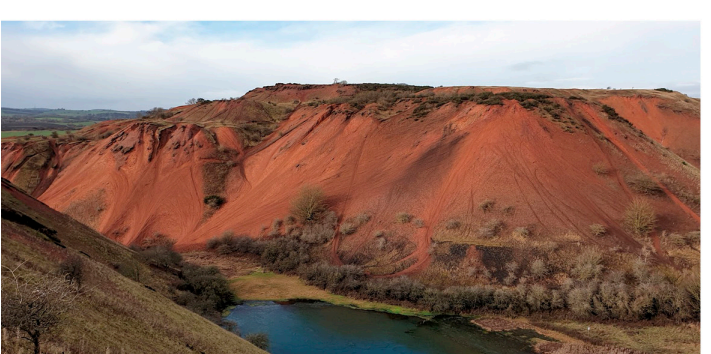

g)Greendykes Shale Bing. West Lothian.

Source: Neil's Hillwalking Exploits

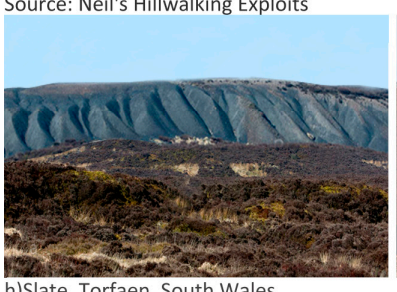

h)Slate. Torfaen, South Wales.

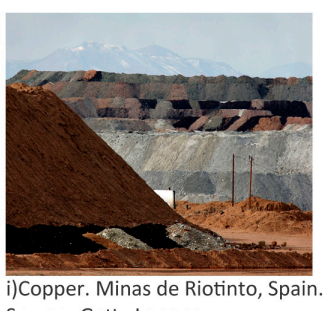

Copper Minas de Riotinto, Spain Source: Getty Images

Reused

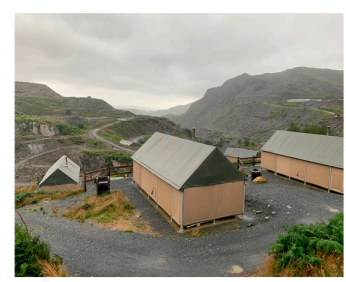

I,m) Glamping at the Slate Blaenau Source: TripAdviso

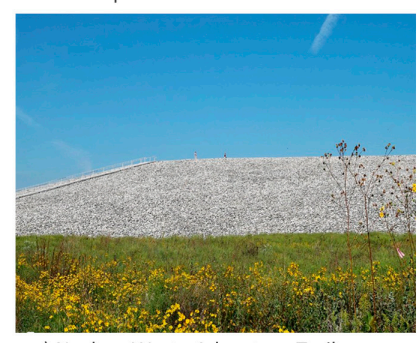

n,o) Nuclear Waste Adventure Trail.

Weldon Spring Center. Source:

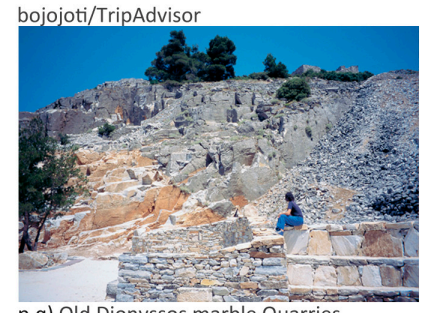

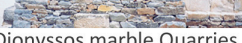

p,q) Old Dionyssos marble Quarries

Photos from the archives of Sculpted Architectural Landscapes: Nella Golanda + Aspassia Kouzoupi. Use by permission from the authors.

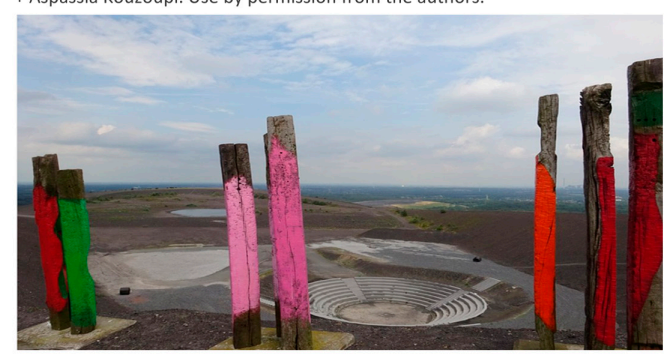

r) Halde Haniel, Germany.

ource: bojojoti/TripAdvisor

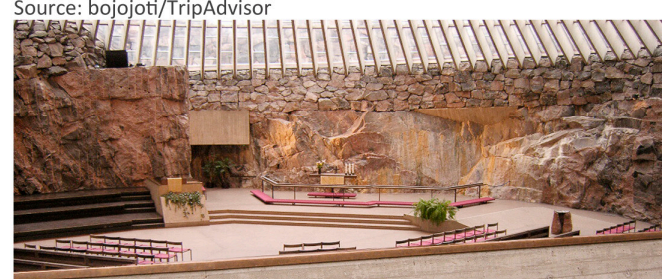

s) Temppeliaukio Church, Helsinki. Inhorw, (@) BY SA 3.0

Figure 6. Waste heaps and elaboration of a general matrix with distinct hypotheses of reuse applicable to the piles of remains. [The pictures of the first column represent the mounds of waste without reuse interventions. On the contrary, second column shows cases of study with reuse interventions].

From this elaboration of classes for the reuse, it is evident that the selected waste piles have been mainly reused in situ for recreational and touristic purposes. Most of them have been considered as monumental containers of spaces (both indoors and outdoors), integrated in the landscape and always communicating with the preexistence and its meaning. These main concepts have been crucial to deductively derive an architectural application methodology, based on the local reuse of the abandoned industrial waste heaps. As will be discussed in the following section, the proposed new 
methodology represents the main result of this research work, at an early stage, applied to a specific location. Therefore, this work adds an important new contribution to the field and an advance to the state-of-the-art. The elaborated systematic methodology identifies and organizes the main examples of waste piles, to formulate new hypothesis and general criteria of reconversion, resolving the existing gap in both architectural and theoretical domains. To the best of the authors' knowledge, there is not any similar schematization in the literature, and the idea of dealing with the mounds of waste in the architectural and landscape sectors has been slightly approached until now.

Table 2. Elaboration of classes for the reuse of waste heaps and synthesis of the discussed cases of study.

\begin{tabular}{|c|c|c|c|c|}
\hline Class & Discussion & Case of Study & Type of Waste & Use \\
\hline Detachment & $\begin{array}{l}\text { It presupposes the insertion of small } \\
\text { ephemeral structures in proximity } \\
\text { to waste piles, not interfering with } \\
\text { them. There are respect and a } \\
\text { valorization of the pre-existence by } \\
\text { contemplating it. }\end{array}$ & $\begin{array}{l}\text { Blaenau Ffestiniog, } \\
\text { North Wales. }\end{array}$ & Slate. & Touristic. \\
\hline Equality & $\begin{array}{l}\text { It consists in treating the } \\
\text { accumulation of scraps as the other } \\
\text { components of the landscape. The } \\
\text { waste accumulation represents not } \\
\text { an isolated factor to } \\
\text { monumentalizing but a territorial } \\
\text { component able to interact } \\
\text { with people. }\end{array}$ & $\begin{array}{l}\text { Weldon Spring } \\
\text { Centre, St. Charles } \\
\text { County, Missouri. }\end{array}$ & Nuclear. & $\begin{array}{l}\text { Recreational, } \\
\text { touristic. }\end{array}$ \\
\hline $\begin{array}{c}\text { Binomial } \\
\text { monumentality-human } \\
\text { interaction }\end{array}$ & $\begin{array}{l}\text { It includes both monumentality and } \\
\text { the interaction components, exalting } \\
\text { the waste accumulation as a } \\
\text { prominent installation, opening it at } \\
\text { people visits. }\end{array}$ & $\begin{array}{l}\text { Dionyssos quarries, } \\
\text { Greece. }\end{array}$ & Marble. & Touristic. \\
\hline Naturalistic & $\begin{array}{l}\text { Mimesis with the landscape. The } \\
\text { waste heap is treated as an integral } \\
\text { part of the landscape and not as an } \\
\text { extraneous object to contemplate. } \\
\text { This criterion allows the } \\
\text { introduction of recreational and } \\
\text { cultural structures only if they } \\
\text { appear "hidden" in the } \\
\text { waste accumulation. }\end{array}$ & $\begin{array}{l}\text { Slag heap Haniel, } \\
\text { Germany. }\end{array}$ & Coal. & $\begin{array}{l}\text { Recreational, } \\
\text { touristic. }\end{array}$ \\
\hline Architectonic & $\begin{array}{l}\text { It completely exalts the meaning of } \\
\text { the pile of remains giving it the } \\
\text { function of "shell." The waste pile } \\
\text { can contain buildings and } \\
\text { renewed spaces. }\end{array}$ & $\begin{array}{l}\text { Temppeliaukio } \\
\text { Church, Helsinki. }\end{array}$ & $\begin{array}{l}\text { Mix of solid blocks } \\
\text { and granite wastes. }\end{array}$ & Religious. \\
\hline
\end{tabular}

\section{Proposed Application Methodology for the Architectural Reuse of the Waste Heaps and Discussion}

The current research, starting from an innovative review about the waste reuse theory and practice, is interested in investigating new reuse methods for the piles of discarded material located in the Estremoz Anticline, in Portugal (as previously described). The general objective of the investigation is to re-qualify the industrial landscape using volumes and materials available in situ (waste mounds), to preserve the historical and industrial memory of the place. Innovative strategies are proposed to demonstrate the possibility of transforming a disused landscape into an attractive and visited one, having an associated aesthetic value. In accordance with the principles previously elaborated, the investigation is mainly focused on re-establishing a recreational and touristic purpose, planning the area, revitalizing the dead landscape with new functions, and considering the heaps of remains as monumental "containers" of spaces integrated in the landscape and communicating with the pre-existence. The challenge is to create buildings inside and above the accumulations of scraps [60], beginning from the analysis of the Stone Church in Helsinki. The objective of the ongoing research involves the waste piles in the process of rehabilitation of the abandoned extractive site and integrating them into the revitalized landscape. 
The practical analysis of the cases of study and the theoretical understanding about the circular economy have jointly formed the basis of the research to comprehend how the reuse optical can advance in the architectural discipline, following a new methodology. The investigation adsorbs the main concepts, described in the preceding sections, to materially deal with the problem of the mounds of waste from quarries. These foremost concepts can be shortened as follows:

- The beauty corresponds to the essence of a thing and not to the idea of its form [1];

- The rehabilitation process should protect the traces of the industrial activity, as testimonies of the history of the place [2];

- The reuse is an indispensable component to comprehend how to reprocess an obsolete matter into something that is put back into cycles of use [23];

- The "superuse" is a method that differs from simple "reuse" for the need to propose future scenarios for the rejected material [33];

- It is necessary to create different business opportunities "discovering" local and pre-used materials and not to use new and innovative technologies [40];

- It is challenging to act in situ, not exporting the waste material;

- One must consider the giant waste heaps as monumental components, integrated into the landscape and interactive with people.

This paper proposes the development of a useful and practical methodology, never experienced and applied before, to deepen the waste question in the architectural context, considering the waste piles as principal subjects of the rehabilitation process of an extractive area. Being an interdisciplinary topic, the reuse of industrial waste heaps connects many disciplines at the same time. For this reason, the first methodological step was inserting the reuse theme inside a broad disciplinary context, primarily investigating the landscape sector (with a focus on the landscape of abandonment) [2] and the rehabilitation procedures of quarries [3]. The succeeding develops the proposed methodology, starting from the analysis of the Portuguese case of study and the material identification of the area on the territorial maps, linking the mounds of remain with their quarries. Using this identification, one realizes the vast dimensions of the zone (about $280 \mathrm{~km}^{2}$ ) and the significant number of pits and waste piles located on it (nearly 200). After planning the area, conferring it renovated functions from a landscape point of view, it is essential to select some portions of it to consider as reference unities.

\section{How is it Possible to Advance with this Selection Operation?}

The answer consists in establishing selection criteria creating a waste catalogue with different types of information. The investigation, having already formulated a criteria list for the selection of quarries [3], pays attention to the elaboration of criteria exclusively related to the waste piles. Eventual principles could be associated with those described in the following table (Table 3).

Table 3. Criteria list for the selection of specific waste piles and reference unities.

\begin{tabular}{c}
\hline Criteria \\
\hline Presence of vegetation cover above the mounds of waste \\
\hline Stability of the waste accumulation \\
\hline Proximity to main streets/roads \\
Proximity to touristic attractions \\
Urban context \\
Rural context \\
Visual impact degree
\end{tabular}


The research, to help in the selection of reference unities, associates this criteria list with the reuse classes illustrated in Table 2. In this way, the investigation creates a reference model of interventions (Figure 7) to comprehend which type of reuse to adopt, in precise situations, for the piles of remains.

\begin{tabular}{|c|c|c|c|c|c|c|c|c|c|c|c|c|c|c|c|}
\hline \multirow{2}{*}{ Criteria } & \multicolumn{2}{|c|}{ Heap size } & \multirow{2}{*}{$\begin{array}{c}\text { Presence } \\
\text { of cover } \\
\text { vegetation }\end{array}$} & \multicolumn{2}{|c|}{ Stability of the heap } & \multirow{2}{*}{$\begin{array}{l}\text { Proximity } \\
\text { to main } \\
\text { streets }\end{array}$} & \multirow{2}{*}{$\begin{array}{l}\begin{array}{l}\text { Proximity } \\
\text { to } \\
\text { attractions }\end{array} \\
\end{array}$} & \multicolumn{2}{|c|}{$\begin{array}{l}\text { Context } \\
\text { typology }\end{array}$} & \multicolumn{3}{|c|}{ Typology of intervention } & \multicolumn{2}{|c|}{$\begin{array}{c}\text { Visual impact } \\
\text { degree }\end{array}$} & \multirow[t]{2}{*}{ Architectural result } \\
\hline & $\begin{array}{l}\text { Small } \\
\text { Medium }\end{array}$ & Large & & Low & High & & & Urban & Rural & Ephemeral & Moderate & Intense & Low & High & \\
\hline Detachment & & - & & - & & & & - & - & - & & & - & & Touristic structures \\
\hline Equality & - & - & & & - & • & & • & - & - & & & - & & $\begin{array}{l}\text { Relax spaces } \\
\text { Walkways } \\
\text { Viewpoints }\end{array}$ \\
\hline $\begin{array}{c}\text { Binomial } \\
\text { monumentality- } \\
\text { human } \\
\text { interaction }\end{array}$ & - & - & & & - & & & - & - & & - & & & - & $\begin{array}{l}\text { Touristic spaces } \\
\text { Public parks }\end{array}$ \\
\hline \multirow[b]{2}{*}{ Naturalistic } & - & - & - & & - & & & & - & - & & & - & & Terraced gardens \\
\hline & - & - & - & & - & - & & & - & & - & & - & & $\begin{array}{l}\text { Recreational structures } \\
\text { Natural parks }\end{array}$ \\
\hline \multirow{2}{*}{ Architectonic } & - & & & & - & • & & - & & & & - & • & & $\begin{array}{l}\text { Touristic buildings } \\
\text { Buildings with civil purposes } \\
\text { Buildings for shopping }\end{array}$ \\
\hline & • & & & & - & & - & & - & & & - & • & & $\begin{array}{l}\text { Wineries } \\
\text { Touristic buildings } \\
\text { Food courts }\end{array}$ \\
\hline
\end{tabular}

Figure 7. Description of a reference model for reuse interventions of waste piles.

After determining these requirements, one selects up to three subareas (arising from the choice of the reference standards), in which to applicate the research proposal (Figure 8a). Through reference unities, it is achievable to replicate them (if necessary), for other parts of the total area, either in an identical manner or with minor variations. In the subsequent steps of the methodological process (illustrated in Figure 8b), having the research use an interdisciplinary approach, the architecture field is flanked by other disciplines as follow:

- Architecture and landscape: Planning the entire area, from a landscape point of view, to confer general renewed uses to include in the process of rehabilitation.

- Architecture and geology: Combined to evaluate the risk of potential rock movements and instabilities, using a structural and geological characterization of quarries and escombreiras (waste heaps).

- Architecture and civil engineering: Binomial to investigate building construction techniques in mounds of marble waste. It is interesting to achieve the most straightforward and cheapest solution, despite the apparent complexity of the theme.

- Architecture and materials technology: Representing an appropriate combination to examine the integration between the marble remains and new materials and technologies. The purpose is to harmonize a heavy material with others, useful for the creation of new buildings.

- Architecture and economy: It is a necessary dualism to estimate future costs of the construction and conceive an economic comparison among two hypotheses; that of leaving the accumulation of waste and the other one of demolishing them.

Following this objective and methodology, the research intends to confer a new meaning to what is ordinary, working with waste to preserve the industrial memory of a place and not exporting marble residues from the context where they reside [61]. These interventions are blended in the surrounding territory, connecting the landscape discipline with architecture and planning, using interdisciplinarity as the central strategy and a tool for change. 

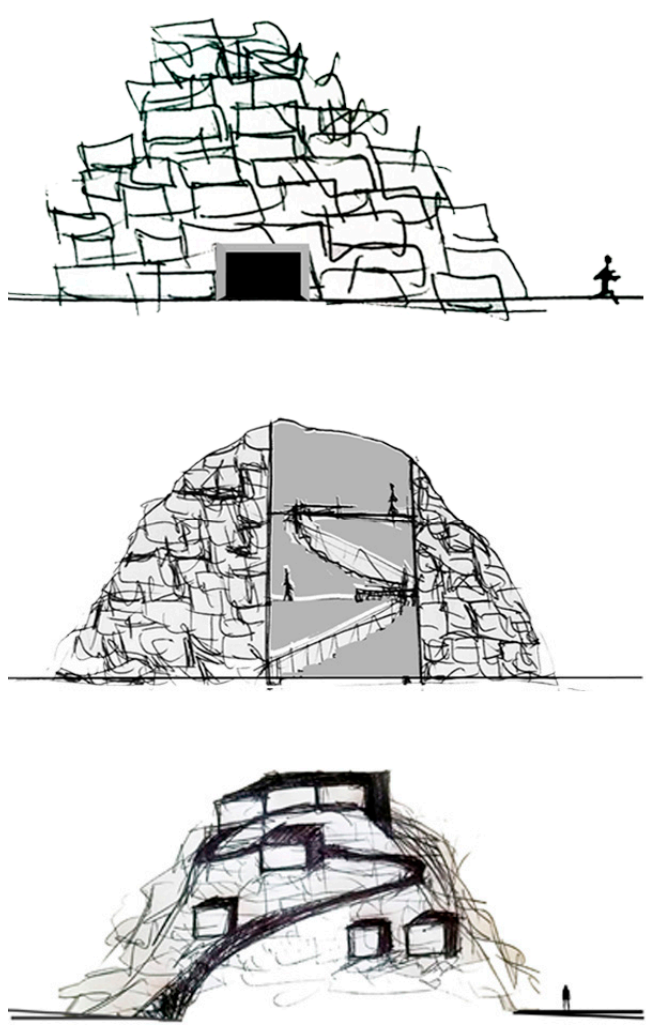

(a)

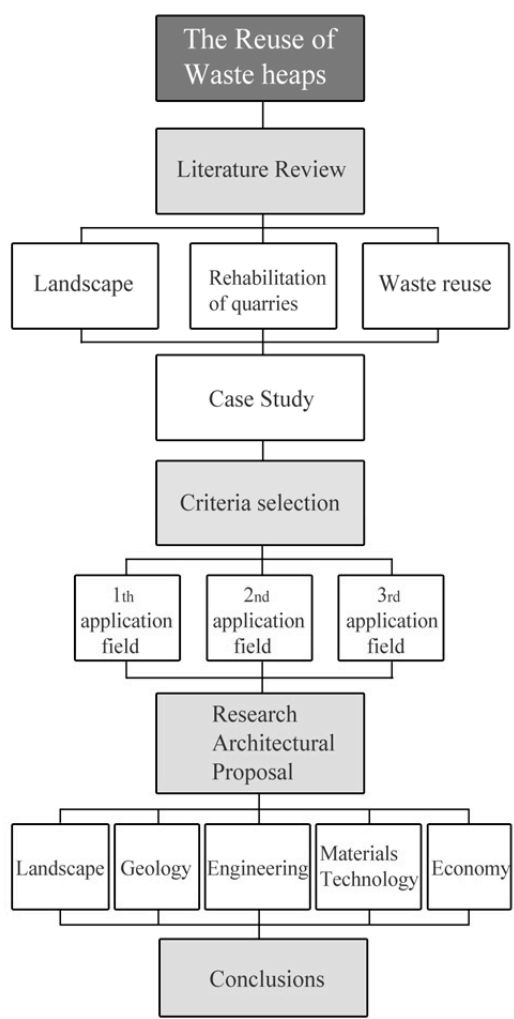

(b)

Figure 8. (a) Building inside, between, and above the waste heap. Source: Katia Talento. (b) Block diagram summarizing the proposed methodology for the reuse of waste heaps in the Estremoz Anticline.

\section{Conclusions}

This article addressed the problem associated with the massive accumulations of waste from extraction activity. These products are usually excluded from the process of rehabilitation because they are considered disturbing elements without economic and architectural value. Recently, greater awareness towards environmental concern considers the hypothesis of introducing waste material in the procedure of the rehabilitation of quarries. In many places, intervention actions are being developed, but they are carried out in a disjointed manner and without a dedicated support methodology that defines and systematizes the criteria to adopt. Through architectural interventions, the rehabilitation of quarries and landscape can obtain a more significant advantage, transforming the "artificial mountains" of waste into new spaces with renewed functions. According to the presented and broader research, the article has analyzed and discussed a case study in Portugal that provides a methodology for the current trend of the reuse of waste heaps. This methodology (never experienced before) represents a starting point to investigate innovative solutions of reuse of the remains from the extraction industry. The inclusion of the inert material in the quarry rehabilitation represents an advantage that can be addressed by the architecture discipline to transform and innovate the landscape, respecting the principles of the circular economy. Giving a new life cycle to the "dead" components of the territory has repercussions on the local economy and the management of the land, which highly contributes to a sustainable use of the planet and to further improve the concept of sustainability and circular economy.

Author Contributions: Conceptualization, K.T., methodology, K.T. and M.A.; investigation, K.T.; writing一original draft preparation, K.T.; writing-review and editing, K.T., M.A. and J.C.K. All authors have read and agreed to the published version of the manuscript.

Funding: This research was funded by the FCT-Fundação para a Ciência e a Tecnologia, under grant number SFRH/BD/133777/2017. 
Acknowledgments: The first author thanks the FCT-Fundação para a Ciência e a Tecnologia, under grant number SFRH/BD/133777/2017. The work of J. C. Kullberg was supported by national funds from Fundacão para a Ciência e a Tecnologia (FCT) through the research unit UID/GEO/04035/2013 (GeoBioTec).

Conflicts of Interest: The authors declare no conflict of interest.

\section{References}

1. De Poli, M.; Incerti, G. Atlante dei Paesaggi Riciclati; Skira Editore: Milan, Italy, 2014.

2. Talento, K.; Amado, M.; Kullberg, J.C. Landscape-A Review with a European Perspective. Land 2019 , 8, 85. [CrossRef]

3. Talento, K.; Amado, M.; Kullberg, J.C. Quarries: From Abandoned to Renewed Places. Land 2020, 9, 136. [CrossRef]

4. El-Fadel, M.; Sadek, S.; Chahine, W. Environmental Management of Quarries as Waste Disposal Facilities. Environ. Manag. 2001, 27, 515-531. [CrossRef] [PubMed]

5. Dal Sasso, P.; Ottolino, M.A.; Caliandro, L.P. Identification of Quarries Rehabilitation Scenarios: A Case Study Within the Metropolitan Area of Bari (Italy). Environ. Manag. 2012, 49, 1174-1191. [CrossRef] [PubMed]

6. Baillie, P.W. Auditing a flooded quarry prior to marina development. Environ. Manag. 1992, 16, 531-540. [CrossRef]

7. Hebel, D.E.; Wisniewska, M.H.; Heisel, F. Building from Waste: Recovered Materials in Architecture and Construction; Birkhäuser: Basel, Switzerland, 2014.

8. Pongrácz, E.; Pohjola, V.J. Re-defining waste, the concept of ownership and the role of waste management. Resour. Conserv. Recycl. 2004, 40, 141-153. [CrossRef]

9. European Commission. Directive 2008/98/EC on Waste (Waste Framework Directive). Available online: https://ec.europa.eu/environment/waste/framework/ (accessed on 5 March 2020).

10. Cheyne, I.; Purdue, M. Fitting definition to purpose: The search for a satisfactory definition of waste. J. Environ. Law 1995, 7, 149-168. [CrossRef]

11. Final Guidance Document for Distinguishing Waste from Non-Waste; OECD: Paris, France, 1998; ISSN 1022-2227. Available online: http://www.oecd.org/officialdocuments/publicdisplaydocumentpdf/?doclanguage=en\& cote $=$ env/epoc/wmp(98)1/rev1 (accessed on 5 March 2020).

12. Oxford English Dictionary Online-Waste. Available online: https://krygier.owu.edu/temp/waste_oed.pdf (accessed on 5 March 2020).

13. UNEP Basel Convention on the Control of Transboundary Movements of Hazardous Wastes and their Disposal. J. Environ. Law 1989, 1, 255-277. [CrossRef]

14. World Health Organization Expert Committee. Environmental Health Aspects of Metropolitan Planning and Development. 1965. Available online: https://apps.who.int/iris/handle/10665/40629 (accessed on 5 March 2020).

15. Wilson, D.C.; United Nations Environment Programme; International Solid Waste Association. Global Waste Management Outlook. Available online: https:/www.uncclearn.org/sites/default/files/inventory/unep23092015. pdf (accessed on 5 March 2020).

16. Gourlay, K.A. World of Waste: Dilemmas of Industrial Development; Zed Books: London, UK, 1992.

17. Douglas, M. Purity and Danger; Routledge; Kegan Paul: London, UK, 1966.

18. Steffen, A. Quotefancy. Available online: https:/quotefancy.com/quote/1427273/Alex-Steffen-There-is-nosuch-thing-as-garbage-just-useful-stuff-in-the-wrong-place (accessed on 5 March 2020).

19. Freilla, O. The South Bronx: A Neighbourhood Reclaimed in Actions: What You Can Do with the City; Canadian Centre for Architecture: Montreal, QC, Canada, 2008.

20. Zero Waste America. What Is Waste? Available online: http://www.zerowasteamerica.org/whatiswaste.htm (accessed on 5 March 2020).

21. Bauman, Z. Wasted Lives: Modernity and Its Outcasts; Polity Press: Cambdrige, UK, 2004.

22. Angélil, M.; Siress, C. Going Around in Circles. In Re-Inventing Construction; Ruby Press: Berlin, Germany, 2010; pp. 248-264.

23. Wong, M.H. Reclamation of wastes contaminated by copper, lead, and zinc. Environ. Manag. 1986, 10, 707-713. [CrossRef]

24. Baker-Brown, D. The Re-Use Atlas. A Designer's Guide Towards a Circular Economy; RIBA Publishing: Westminster, UK, 2017. 
25. Bryony, R. Tabula Plena. Forms of Urban Preservation; Lars Muller Publishers: Zurich, Switzerland, 2016.

26. Chung, S.S.; Poon, C.S. A Comparison of Waste Reduction Practices and the New Environmental Paradigm in Four Southern Chinese Areas. Environ. Manag. 2000, 26, 195-206. [CrossRef]

27. House of Commons Environmental Audit Committee Growing a circular economy: Ending the throwaway society. In Third Report of Session 2014-15; The Stationery Office Limited: London, UK, 2014.

28. Rhys, J. Cumulative Carbon Emissions and Climate Change; Institute for Energy Studies: Oxford, UK, 2011.

29. Gorgolewski, M. Resource Salvation: The Architecture of Reuse; John Wiley \& Sons Ltd.: Oxford, UK, 2018.

30. Till, J.; Schneider, T. Invisible Agency. Archit. Des. 2012, 82, 38-43. [CrossRef]

31. Till, J. How Will Architects be Educated in 20 Years Time? Available online: www.jeremytill.net/read/97/ how-will-architects-be-educated-in-20-years-time (accessed on 5 March 2020).

32. Hansen, W.; Christopher, M.; Verbuecheln, M. EU Waste Policy and Challenges for Regional and Local Authorities; Ecologic, Institute for International and European Environmental Policy: Berlin, Germany, 2002.

33. Use It More. Superuse Studios. Available online: https://www.arch2o.com/use-superuse-studios/ (accessed on 5 March 2020).

34. Guy, B.; Nicholas, D. Temporal process in research, green building and material reuse. In Proceedings of the Considering Research: Reflecting Upon Current Themes in Architectural Research, Detroit, MI, USA, 24 April 2011.

35. Lynch, K. Deperire. Rifiuti E Spreco Nella Vita di Uomini E Città; CUEN: Naples, Italy, 1992.

36. Girling, R. Rubbish! Dirt on Our Hands and Crisis Ahead; Eden Project Books: London, UK, 2005.

37. Lynch, K. Wasting Away; Sierra Club Books: San Francisco, CA, USA, 1990.

38. Eurostat Statistics Explained. Waste Statistics. Available online: https://ec.europa.eu/eurostat/statisticsexplained/index.php/Waste_statistics (accessed on 5 March 2020).

39. Waste Atlas 2013 Report. Available online: https://www.iswa.org/fileadmin/galleries/News/WASTE_ATLAS_ 2013_REPORT.pdf (accessed on 5 March 2020).

40. Cohen, D. Earth's Natural Wealth: An Audit. Available online: https://www.newscientist.com/article/ mg19426051-200-earths-natural-wealth-an-audit/?ignored=irrelevant (accessed on 5 March 2020).

41. Mitchell, J. Turning Waste into Building Blocks of the Future City. Available online: https://www.bbc.com/ future/article/20130524-creating-our-cities-from-waste (accessed on 5 March 2020).

42. Rogers, H. Gone Tomorrow: The Hidden Life of Garbage; The New Press: New York, NY, USA; London, UK, 2005.

43. Acocella, A. Architettura Dei Gabbioni. Costruire 2007, 293, 52-53.

44. Mortensrud Church. Jensen \& Skodvin Architects. Available online: https://www.archdaily.com/1929/ mortensrud-church-jsa (accessed on 5 March 2020).

45. Frearson, A. Apartment No. 1 by AbCT. Available online: https://www.dezeen.com/2013/05/10/apartmentno-1-by-abct/ (accessed on 5 March 2020).

46. Howarth, D. David Chipperfield's Valentino flagship store opens in New York. Dezeen. 11 September 2014. Available online: https://www.dezeen.com/2014/09/11/david-chipperfield-valentino-flagship-store-fifthavenue-new-york/ (accessed on 5 March 2020).

47. Knight, E. A Reflection on Belzec. The National Holocaust Centre and Museum. Available online: https: //www.holocaust.org.uk/blog/belzec (accessed on 5 March 2020).

48. ArchDaily. Piedra Tosca Park/RCR Arquitectes. Available online: https://www.archdaily.com/806228/piedratosca-park-rcr-arquitectes (accessed on 5 March 2020).

49. Smithson, R. A Sedimentation the Mind: Earth Projects. In Robert Smithson: The Collected Writings; University of California Press: Berkeley, CA, USA, 1996; pp. 110-111.

50. Smithson, R. A Provisional Theory of Non-sites. In Robert Smithson: The Collected Writings; University of California Press: Berkeley, CA, USA, 1968; p. 364.

51. Alloway, L. Sites/Nonsites. In Robert Smithson: Sculpture; Smithmark Pub: Ithaca, NY, USA, 1983; pp. $42-43$.

52. Hutton, J. Reciprocal Landscapes: Stories of Material Movements; Routledge: Philadelphia, PA, USA, 2019.

53. Deepankar, K.A. Feasibility of waste marble powder in concrete as partial substitution of cement and sand amalgam for sustainable growth. J. Build. Eng. 2018, 15, 236-242.

54. Ulubeyli, G.C.; Artir, R. Properties of Hardened Concrete Produced by Waste Marble. Procedia Soc. Behav. Sci. 2015, 195, 2181-2190. [CrossRef]

55. Simão, J.; Freire, A.C.; Farto, H. Caracterização de Rejeitados de Escombreiras de Pedreiras de Rocha Ornamental Para Aplicação em Camadas Não Ligadas de Pavimentos Rodoviários; Duraspace: Lisbon, Portugal, 2016. 
56. Silva, C.F.; Esteves, L.D. The Mounds of Estremoz Marble Waste: Between refuse and reuse. In Waste 2015-Solutions, Treatments and Opportunities; CRC press: London, UK, 2015; pp. 305-310.

57. Gallent, N.; Mace, A.; Tewdwr-Jones, M. Mainland Europe and Britain Compared Introduction. In Second Homes; Routledge: London, UK, 2017; pp. 127-143.

58. Holden, R. New Landscape Design; Architectural Press: Oxford, UK, 2003.

59. Chmielewska, M.; Otto, M. Revitalisation of spoil tips and socio-economic polarisation-A case study of Ruhr area (Germany). Environ. Socio Econ. Stud. 2014, 2, 45-56. [CrossRef]

60. Talento, K.; Amado, M.; Kullberg, J.C. Eco-friendly reuse of marble wastes in landscape and architecture. Sustain. City XIII WIT Trans. Ecol. Environ. 2019, 238, 665-677.

61. Talento, K.; Miguel, A.; Kullberg, J.C. The metamorphosis of the landscape: The adaptive reuse of marble waste. In Proceedings of the 5th International Conference on Architecture and Built Environment with AWARDs S.ARCH 2018 CONFERENCE PROCEEDING, Erlangen, Germany, 22 May 2018.

(C) 2020 by the authors. Licensee MDPI, Basel, Switzerland. This article is an open access article distributed under the terms and conditions of the Creative Commons Attribution (CC BY) license (http://creativecommons.org/licenses/by/4.0/). 